\title{
Comparison of methods for detecting fungi in Silybum marianum (L.) Gaertn. seeds
}

\author{
Agnieszka Rosińska*, Magdalena Jarosz, Dorota Szopińska, \\ Hanna Dorna, Krystyna Tylkowska
}

\author{
Department of Seed Science and Technology \\ Faculty of Horticulture and Landscape Architecture, Poznań University of Life Sciences \\ Szamotulska 28, Baranowo, 62-081 Przeźmierowo, Poland
}

\begin{abstract}
Milk thistle (Silybum marianum (L.) Gaertn.) is one of the most important medicinal plants. The fungi infesting its seeds may negatively influence their germination and health-promoting properties. However, there is no standard method for S. marianum seed health testing. The aim of this study was to find a suitable method for the detection and identification of fungi in/on milk thistle seeds. The following tests were used: deep-freeze blotter test, blotter test with an addition of mannitol, blotter test with an addition of polyethylene glycol, agar test on potato-dextrose agar (PDA), agar test on PDA after seed disinfection, agar test on reduced PDA and an agar test on reduced PDA after seed disinfection. Seeds were incubated for 10 and 14 days. The most prevalent fungi were: Alternaria alternata, Botrytis cinerea, Cladosporium spp., Fusarium spp., Penicillium spp., Rhizopus nigricans and Verticillium spp. A deep-freeze blotter test followed by a blotter test with an addition of mannitol and a blotter test with an addition of polyethylene glycol performed for 14 days could be recommended for the further study of milk thistle seed health testing, as they favoured the growth of the most important fungi.
\end{abstract}

Key words: agar test, blotter test, milk thistle, seed health

\section{INTRODUCTION}

Milk thistle (Silybum marianum (L.) Gaertn.) is an annual herbal plant originating from the Mediterranean Region. It belongs to the Asteraceae family and is one of the most important medicinal plants cultivated commercially for seeds in Europe (Seidler-Łożykowska 2009). From the botanical point of view, the dispersal unit of milk thistle is achene, termed in practice as the seed. Milk thistle seeds have been used for 2,000 years as an herbal remedy and as food (Ghavani and Ramin 2007). The seeds contain a mixture of flavonolignans, a complex of isomers of silybin, silychristin and sylidianin, called sylimarin. The sylimarin complex protects liver cells against various hepatitis viruses and toxins (Morazonni and Bombardelli 1995). It exhibits antagonistic action against amanitin - a toxin produced by Amanita phalloides (Vaill. ex Fr.) Link, a fungus commonly known as the death cap - and inhibits its uptake by the liver. Milk thistle seeds can also be added to bakery products as a health-promoting dietary supplement, without affecting the smell, flavour, colour or physiochemical properties of food (Sadowska 2006).

Numerous fungi have been reported on milk thistle seeds, including: Alternaria alternata (Fr.) Keissler, Botrytis cinerea Pers ex Pers,

\footnotetext{
*Corresponding author.

Tel.: +48 6181635 88; fax: +48 6181422 91;

e-mail: seed@up.poznan.pl (A. Rosińska).
} 
Cladosporium cladosporioides (Fres.) de Vries, Epicoccum purpurascens Ehrenberg, Fusarium spp., Mucor hiemalis Wehmer, Penicillium chrysogenum Thom, P. decumbens Thom, Rhizopus nigricans Ehrenberg and Stemphylium botryosum Wallr. (Machowicz-Stefaniak and Zimowska 2000). Some of these fungi, such as A. alternata, B. cinerea, Fusarium spp., Mucor sp., Penicillium spp. and Rhizopus sp., can be responsible for the poor germination of the seeds (personal observation). Additionally, the fungi produce secondary metabolites (mycotoxins) that are harmful to humans and animals (Aziz et al. 1998, Logrieco et al. 2009). The presence of aflatoxins in milk thistle herbal supplements was reported by Tournas et al. (2012). Moreover, Arroyo-Manzanares et al. (2013) detected trichothecenes (HT-2, T-2) and zearalenone in the seeds and natural extract of milk thistle. However, there is no standard method for milk thistle seed health testing. Blotter and agar tests are commonly used for the identification of seed-transmitted fungi (ISTA 2012). However, seed germination may be a factor severely limiting the detection of pathogens, especially in blotter tests. Various modifications, such as deep freezing or the water restriction technique, have been proposed to prevent germination (ISTA 2012, Machado et al. 2003, 2004, 2008, Mathur and Kongsdal 2003). The main problems in the agar test, on the other hand, are fast-growing saprotrophs such as Mucor spp. and Rhizopus spp., which may overgrow the pathogens. These fungi usually contaminate seed surfaces, therefore disinfection often results in their removal (Sauer and Burroughs 1986, Szopińska et al. 2012). The other problem in using the agar test may be the lack of sporulation of the fungi. To overcome this difficulty, a medium with a reduced content of potato-dextrose agar has been proposed (Kohen, personal communication).

The goal of this study was to determine the most efficient methods for detecting fungi in milk thistle seeds.

\section{MATERIAL AND METHODS}

Five samples of milk thistle seeds produced in Central and Northern Poland in the years 2005 (sample I), 2006 (sample II), 2009 (sample III) and 2010 (sample IV and V) were used in the experiment. The seed health was tested using a deep-freeze blotter test, a blotter test with an addition of mannitol, a blotter test with an addition of polyethylene glycol (PEG), an agar test on PDA, an agar test on PDA after seed disinfection, an agar test on reduced PDA (RPDA) and an agar test on RPDA after seed disinfection. In each method, 200 seeds (five replicates of 40 seeds) were examined. Ten seeds were sited per $9 \mathrm{~cm}$ diameter Petri dish. In the blotter methods, untreated seeds were placed on six layers of blotter moistened with distilled water or osmotic solutions. In the deep-freeze blotter test the following incubation regime was applied: incubation in the dark at $20^{\circ} \mathrm{C}$ for two days, followed by freezing at $-20^{\circ} \mathrm{C}$ for $24 \mathrm{~h}$, and incubation for seven and 11 days at $20^{\circ} \mathrm{C}$. Alternating $12 \mathrm{~h}$ periods of dark and NUV light were applied during the last stage of incubation to promote sporulation. In the case of the blotter test, two different osmotic solutions viz. $5 \mathrm{ml}$ of mannitol solution with an osmotic potential -1.5 MPa (112.2 g mannitol dissolved in $1 \mathrm{~L}$ sterile distilled water) and $5 \mathrm{ml}$ of PEG solution with an osmotic potential -1.0 MPa (284 g PEG dissolved in $1 \mathrm{~L}$ sterile distilled water) were added to each Petri dish instead of distilled water to moisten the blotter and incubated at $20^{\circ} \mathrm{C}$ for 10 or 14 days under alternating cycles of $12 \mathrm{~h}$ dark and $12 \mathrm{~h}$ NUV light.

For the agar test, non-disinfected and surfacedisinfected seeds were placed on a solidified PDA (Merck KGaA, Darmstadt, Germany) or reduced PDA media (RPDA: $10 \mathrm{~g}$ of agar extra pure, Merck KGaA, Darmstadt, Germany; $12 \mathrm{~g}$ of potato dextrose agar, Merck KGaA, Darmstadt, Germany; 1,000 ml of distilled water) with an addition of $100 \mathrm{ppm}$ of streptomycin sulphate to prevent the occurrence of bacteria. Seeds were incubated for 10 and 14 days under alternating cycles of darkness and NUV light. For surface disinfection, the seeds were soaked in a $1.0 \%$ aqueous solution of sodium hypochlorite $(\mathrm{NaClO})$ for $10 \mathrm{~min}$ and rinsed thrice with sterile distilled water and surface dried between sterile blotters.

Using a stereomicroscope and a compound microscope, fungi were identified on the basis of their growth, colony pattern, observation mycelium and spores with reference to Malone and Muskett (1964), Ellis (1971, 1976), Watanabe (2002) and Mathur and Kongsdal (2003).

All results were analysed using STAT software, by means of a two-way analysis of variance after transforming the percentage values according to the Bliss formula: $\mathrm{y}=\operatorname{arc} \sin [\operatorname{sqr}(\mathrm{x} / 100)]$. Means were compared with the Duncan multiple range test.

\section{RESULTS AND DISCUSSION}

Several fungi were detected on milk thistle seeds through the use of standard and modified blotter 
and agar tests. The most important and frequently occurring fungi were: A. alternata, B. cinerea, Cladosporium spp. Fusarium spp., Penicillium spp., R. nigricans, and Verticillium spp. (Tabs 1-7). Additionally, Acremonium strictum (Corda) W. Gams, Alternaria spp., Aspergillus flavus Link, A.fumigatus Fresen., A. niger Tiegh., Aureobasidium sp., Bipolaris sp., Cephalosporium acremonium Corda, Drechslera sp., E. purpurascens, Mucor sp., Gonatobotrys simplex Corda, Nigrospora sp., Papulaspora sp., Sordaria sp., Stachybotrys sp., S. botryosum, Thamnidium elegans Link., Trichothecium roseum Link., Trichoderma spp. and Ulocladium spp. were identified sporadically and often detected on seeds of only one of the samples (Tab. 8). Most of these fungi were also isolated from the stems of milk thistle by Cwalina-Ambroziak et al. (2012). The authors reported that among the potential pathogens the predominant species was A. alternata, while fungi of the genus Fusarium were identified less frequently, and Rhizoctonia solani, B. cinerea and Phoma spp. were recovered only sporadically.

In the present experiment, samples varied in terms of the percentage of seed infestation with individual fungi, however A. alternata prevailed. Alternaria alternata is the most common Alternaria species. This saprotrophic fungus can be found all over the world (Scheffer 1992). High milk thistle seed infestation by A. alternata was reported by Machowicz-Stefaniak and Zimowska (2000). This seems to be particularly worrisome, because this fungus is capable of producing several mycotoxins, such as alternariol, alternariol monomethyl ether, altenuene, altertoxins I, II and III, and tenuazonic acid (Logrieco et al. 2009). In our experiment, $A$. alternata was detected in all of the examined seed samples, but samples IV and V produced in 2010 were infested in a much higher extent than older ones. The level of detection varied depending on the sample, the method applied and the duration of the test. The highest percentages of seeds infested by A. alternata were observed in the deep-freeze blotter test and in the blotter test with an addition of mannitol, especially when seed incubation was prolonged (Tab. 1). Prolongation of the blotter test with an addition of mannitol also positively affected the growth of $B$. cinerea (Tab. 2). For Cladosporium spp. and Penicillium spp., the highest level of detection was noted in the

Table 1. Occurrence of Alternaria alternata on milk thistle seeds, using different methods and periods of incubation (percentage of infested seeds)

\begin{tabular}{|c|c|c|c|c|c|c|c|}
\hline \multirow{2}{*}{ Method } & \multirow{2}{*}{$\begin{array}{c}\text { Period of } \\
\text { incubation } \\
\text { (days) }\end{array}$} & \multicolumn{5}{|c|}{ Sample } & \multirow{2}{*}{ Mean for method } \\
\hline & & I & II & III & IV & $\mathrm{V}$ & \\
\hline \multirow{2}{*}{ DFBT* } & 10 & 16.5 & 16.5 & 65.5 & 91.5 & 99.5 & 57.9 fg** \\
\hline & 14 & 27.0 & 31.5 & 72.0 & 92.5 & 99.5 & $64.5 \mathrm{~h}$ \\
\hline \multirow{2}{*}{$\mathrm{BT}+\mathrm{PEG}$} & 10 & 2.0 & 4.0 & 62.0 & 84.5 & 97.5 & $50.0 \mathrm{e}$ \\
\hline & 14 & 4.5 & 4.0 & 62.5 & 86.5 & 98.0 & $51.1 \mathrm{e}$ \\
\hline \multirow{2}{*}{$\mathrm{BT}+\mathrm{MAN}$} & 10 & 23.0 & 24.0 & 72.0 & 79.5 & 93.5 & $58.4 \mathrm{f}$ \\
\hline & 14 & 29.0 & 39.0 & 74.5 & 81.5 & 95.0 & $63.8 \mathrm{gh}$ \\
\hline \multirow{2}{*}{ PDA } & 10 & 0 & 0 & 63.0 & 69.0 & 66.5 & $39.7 \mathrm{bc}$ \\
\hline & 14 & 0 & 0 & 66.0 & 72.0 & 76.5 & $42.9 \mathrm{c}$ \\
\hline \multirow{2}{*}{ PDA D } & 10 & 0 & 0.5 & 14.0 & 53.0 & 53.5 & $24.2 \mathrm{a}$ \\
\hline & 14 & 0 & 0.5 & 16.5 & 61.0 & 65.5 & $28.7 \mathrm{a}$ \\
\hline \multirow{2}{*}{ RPDA } & 10 & 0 & 0.5 & 63.0 & 86.5 & 91.0 & $48.2 \mathrm{~d}$ \\
\hline & 14 & 0 & 0.5 & 72.0 & 88.5 & 93.0 & $50.8 \mathrm{de}$ \\
\hline \multirow{2}{*}{ RPDA D } & 10 & 0 & 2.0 & 12.0 & 59.5 & 73.5 & $29.4 \mathrm{a}$ \\
\hline & 14 & 0.5 & 6.0 & 30.0 & 65.0 & 81.0 & $36.5 \mathrm{~b}$ \\
\hline \multicolumn{2}{|c|}{ Mean for sample } & $7.3 \mathrm{a}$ & $9.2 \mathrm{~b}$ & $53.2 \mathrm{c}$ & $76.5 \mathrm{~d}$ & $84.5 \mathrm{e}$ & \\
\hline
\end{tabular}

*DFBT - deep-freeze blotter test, BT+PEG - blotter test with an addition of polyethylene glycol, BT+MAN - blotter test with an addition of mannitol, PDA - agar test on potato dextrose agar, PDA D - agar test on potato dextrose agar after surface seed disinfection, RPDA - agar test on reduced potato dextrose agar, RPDA D - agar test on reduced potato dextrose agar after surface seed disinfection

**Means followed by the same letters, separately for methods and for samples, are not significantly different from each other, according to the Duncan test $(\mathrm{p}=0.05)$ 
Table 2. Occurrence of Botrytis cinerea on milk thistle seeds, using different methods and periods of incubation (percentage of infested seeds)

\begin{tabular}{|c|c|c|c|c|c|c|c|}
\hline \multirow{2}{*}{ Method } & \multirow{2}{*}{$\begin{array}{c}\text { Period of } \\
\text { incubation } \\
\text { (days) }\end{array}$} & \multicolumn{5}{|c|}{ Sample } & \multirow{2}{*}{ Mean for method } \\
\hline & & I & II & III & IV & $\mathrm{V}$ & \\
\hline \multirow{2}{*}{ DFBT } & 10 & 4.0 & 2.5 & 0 & 1.0 & 4.0 & $2.3 \mathrm{a}$ \\
\hline & 14 & 5.0 & 4.0 & 1.0 & 1.5 & 4.5 & $3.2 \mathrm{a}-\mathrm{c}$ \\
\hline \multirow{2}{*}{$\mathrm{BT}+\mathrm{PEG}$} & 10 & 0 & 0 & 0 & 3.5 & 20.0 & $4.7 \mathrm{ab}$ \\
\hline & 14 & 2.0 & 0 & 0 & 3.5 & 22.0 & $5.5 \mathrm{a}-\mathrm{c}$ \\
\hline \multirow{2}{*}{$\mathrm{BT}+\mathrm{MAN}$} & 10 & 1.5 & 2.0 & 2.0 & 4.0 & 22.0 & $6.3 \mathrm{c}$ \\
\hline & 14 & 5.5 & 10.0 & 8.0 & 9.0 & 25.0 & $11.5 \mathrm{~d}$ \\
\hline \multirow{2}{*}{ PDA } & 10 & 0 & 0 & 0 & 5.0 & 18.5 & $4.7 \mathrm{ab}$ \\
\hline & 14 & 0 & 0 & 0 & 9.0 & 26.0 & $7.0 \mathrm{bc}$ \\
\hline \multirow{2}{*}{ PDA D } & 10 & 0 & 0 & 0 & 1.0 & 32.5 & $6.7 \mathrm{ab}$ \\
\hline & 14 & 0 & 0 & 0 & 2.5 & 35.0 & 7.5 a-c \\
\hline \multirow{2}{*}{ RPDA } & 10 & 0 & 0 & 0 & 3.5 & 24.0 & $5.5 \mathrm{a}-\mathrm{c}$ \\
\hline & 14 & 0 & 0 & 0 & 8.5 & 30.0 & $7.7 \mathrm{bc}$ \\
\hline \multirow{2}{*}{ RPDA D } & 10 & 0 & 0 & 0.5 & 4.0 & 24.5 & $5.8 \mathrm{a}-\mathrm{c}$ \\
\hline & 14 & 0 & 0 & 2.0 & 11.0 & 29.0 & $8.4 \mathrm{c}$ \\
\hline \multicolumn{2}{|c|}{ Mean for sample } & $1.3 \mathrm{a}$ & $1.3 \mathrm{a}$ & $1.0 \mathrm{a}$ & $4.8 \mathrm{~b}$ & $22.6 \mathrm{c}$ & \\
\hline
\end{tabular}

Explanations see Table 1

blotter test with an addition of PEG followed by the blotter test with an addition of mannitol (Tabs 3 and 5). A significantly higher incidence of Fusarium spp. in milk thistle seeds was found in the deep- freeze blotter test after 14 days of seed incubation (Tab. 4). On the other hand, the blotter test with an addition of PEG was not an effective method for the identification of these fungi. The percentage of

Table 3. Occurrence of Cladosporium spp. on milk thistle seeds, using different methods and periods of incubation (percentage of infested seeds)

\begin{tabular}{|c|c|c|c|c|c|c|c|}
\hline \multirow{2}{*}{ Method } & \multirow{2}{*}{$\begin{array}{c}\text { Period of } \\
\text { incubation } \\
\text { (days) }\end{array}$} & \multicolumn{5}{|c|}{ Sample } & \multirow{2}{*}{ Mean for method } \\
\hline & & I & II & III & IV & $\mathrm{V}$ & \\
\hline \multirow{2}{*}{ DFBT } & 10 & 33.5 & 25.5 & 25.0 & 29.0 & 10.0 & $24.6 \mathrm{e}$ \\
\hline & 14 & 40.5 & 29.5 & 26.5 & 30.0 & 10.5 & $27.4 \mathrm{e}$ \\
\hline \multirow{2}{*}{$\mathrm{BT}+\mathrm{PEG}$} & 10 & 20.0 & 45.0 & 36.0 & 46.5 & 16.0 & $32.7 \mathrm{fg}$ \\
\hline & 14 & 22.5 & 48.5 & 38.5 & 49.5 & 21.0 & $36.0 \mathrm{~g}$ \\
\hline \multirow{2}{*}{$\mathrm{BT}+\mathrm{MAN}$} & 10 & 36.5 & 42.5 & 15.5 & 29.5 & 9.0 & $26.6 \mathrm{e}$ \\
\hline & 14 & 39.0 & 47.5 & 20.5 & 32.0 & 10.5 & 29.9 ef \\
\hline \multirow{2}{*}{ PDA } & 10 & 0 & 0 & 1.5 & 15.0 & 6.0 & $4.5 \mathrm{a}$ \\
\hline & 14 & 0 & 0.5 & 2.5 & 17.0 & 6.0 & $5.2 \mathrm{a}$ \\
\hline \multirow{2}{*}{ PDA D } & 10 & 6.0 & 2.0 & 2.0 & 25.5 & 2.5 & $7.6 \mathrm{~b}$ \\
\hline & 14 & 10.0 & 3.0 & 2.5 & 27.5 & 8.0 & $10.2 \mathrm{c}$ \\
\hline \multirow{2}{*}{ RPDA } & 10 & 0.5 & 1.0 & 0.5 & 15.0 & 3.5 & $4.1 \mathrm{a}$ \\
\hline & 14 & 0.5 & 1.0 & 0.5 & 22.0 & 4.0 & $5.6 \mathrm{a}$ \\
\hline \multirow{2}{*}{ RPDA D } & 10 & 10.0 & 9.0 & 8.0 & 21.0 & 18.0 & $13.2 \mathrm{~d}$ \\
\hline & 14 & 12.5 & 9.5 & 9.0 & 22.0 & 19.0 & $14.4 \mathrm{~d}$ \\
\hline \multicolumn{2}{|c|}{ Mean for sample } & $16.6 \mathrm{~b}$ & $18.9 \mathrm{~b}$ & $13.5 \mathrm{a}$ & $27.3 \mathrm{c}$ & $10.3 \mathrm{a}$ & \\
\hline
\end{tabular}

Explanations see Table 1 
Table 4. Occurrence of Fusarium spp. on milk thistle seeds, using different methods and periods of incubation (percentage of infested seeds)

\begin{tabular}{|c|c|c|c|c|c|c|c|}
\hline \multirow{2}{*}{ Method } & \multirow{2}{*}{$\begin{array}{c}\text { Period of } \\
\text { incubation } \\
\text { (days) }\end{array}$} & \multicolumn{5}{|c|}{ Sample } & \multirow{2}{*}{ Mean for method } \\
\hline & & I & II & III & IV & $\mathrm{V}$ & \\
\hline \multirow{2}{*}{ DFBT } & 10 & 2.5 & 1.5 & 4.0 & 12.5 & 15.0 & $7.1 \mathrm{~g}$ \\
\hline & 14 & 3.0 & 6.5 & 4.5 & 17.0 & 24.0 & $11.0 \mathrm{~h}$ \\
\hline \multirow{2}{*}{$\mathrm{BT}+\mathrm{PEG}$} & 10 & 0 & 0 & 0 & 0 & 1.5 & $0.3 \mathrm{a}$ \\
\hline & 14 & 0 & 0 & 0 & 0 & 2.0 & $0.4 \mathrm{a}$ \\
\hline \multirow{2}{*}{$\mathrm{BT}+\mathrm{MAN}$} & 10 & 0 & 0 & 2.5 & 3.5 & 5.0 & $2.2 \mathrm{~b}$ \\
\hline & 14 & 0 & 0 & 2.5 & 4.5 & 5.5 & $2.5 \mathrm{bc}$ \\
\hline \multirow{2}{*}{ PDA } & 10 & 0 & 0.5 & 1.0 & 4.5 & 28.0 & $6.8 \mathrm{c}-\mathrm{e}$ \\
\hline & 14 & 0.5 & 1.5 & 1.0 & 7.0 & 38.5 & 9.7 e-g \\
\hline \multirow{2}{*}{ PDA D } & 10 & 0 & 0 & 2.0 & 7.5 & 26.5 & $7.2 \mathrm{~d}-\mathrm{f}$ \\
\hline & 14 & 0 & 0 & 6.0 & 10.5 & 34.5 & $10.2 \mathrm{fg}$ \\
\hline \multirow{2}{*}{ RPDA } & 10 & 0 & 0 & 0.5 & 5.5 & 13.0 & $3.8 \mathrm{~b}-\mathrm{d}$ \\
\hline & 14 & 0 & 0 & 2.0 & 9.5 & 22.5 & $6.8 \mathrm{~d}-\mathrm{f}$ \\
\hline \multirow{2}{*}{ RPDA D } & 10 & 1.0 & 0 & 0.5 & 4.0 & 17.0 & $4.5 \mathrm{~b}-\mathrm{d}$ \\
\hline & 14 & 1.0 & 0 & 0.5 & 8.0 & 24.5 & $6.8 \mathrm{~d}-\mathrm{f}$ \\
\hline \multicolumn{2}{|c|}{ Mean for sample } & $0.6 \mathrm{a}$ & $0.7 \mathrm{a}$ & $1.9 \mathrm{~b}$ & $6.7 \mathrm{c}$ & $18.4 \mathrm{c}$ & \\
\hline
\end{tabular}

Explanations see Table 1

seeds infested by Fusarium spp. was significantly higher in fresh samples (IV and V), compared with older ones, whereas in these samples the lowest percentage of seeds infested by $R$. nigricans was observed, especially if the deep-freeze blotter test was used (Tab. 6). The PDA test performed for 14 days favoured the growth of Rhizopus sp. to the largest extent. Verticillium spp. was detected

Table 5. Occurrence of Penicillium spp. on milk thistle seeds, using different methods and periods of incubation (percentage of infested seeds)

\begin{tabular}{|c|c|c|c|c|c|c|c|}
\hline \multirow{2}{*}{ Method } & \multirow{2}{*}{$\begin{array}{c}\text { Period of } \\
\text { incubation } \\
\text { (days) }\end{array}$} & \multicolumn{5}{|c|}{ Sample } & \multirow{2}{*}{ Mean for method } \\
\hline & & I & II & III & IV & $\mathrm{V}$ & \\
\hline \multirow{2}{*}{ DFBT } & 10 & 22.0 & 1.5 & 0 & 2.0 & 0.5 & $5.2 \mathrm{~b}$ \\
\hline & 14 & 22.0 & 2.0 & 0 & 2.5 & 1.5 & $5.6 \mathrm{~b}$ \\
\hline \multirow{2}{*}{$\mathrm{BT}+\mathrm{PEG}$} & 10 & 79.5 & 21.5 & 2.5 & 34.0 & 12.5 & 30.0 ef \\
\hline & 14 & 80.0 & 24.0 & 4.0 & 34.5 & 15.0 & $31.5 \mathrm{f}$ \\
\hline \multirow{2}{*}{$\mathrm{BT}+\mathrm{MAN}$} & 10 & 79.5 & 19.0 & 2.5 & 25.5 & 7.0 & $26.7 \mathrm{de}$ \\
\hline & 14 & 82.0 & 26.0 & 4.0 & 31.0 & 7.5 & 30.1 ef \\
\hline \multirow{2}{*}{ PDA } & 10 & 67.0 & 16.5 & 1.0 & 12.5 & 7.0 & $20.8 \mathrm{c}$ \\
\hline & 14 & 75.5 & 21.0 & 1.0 & 15.5 & 9.5 & $24.5 \mathrm{~cd}$ \\
\hline \multirow{2}{*}{ PDA D } & 10 & 4.5 & 0 & 0.5 & 2.5 & 0 & $1.5 \mathrm{a}$ \\
\hline & 14 & 5.0 & 0 & 0.5 & 3.5 & 0 & $1.8 \mathrm{a}$ \\
\hline \multirow{2}{*}{ RPDA } & 10 & 79.5 & 14.0 & 0.5 & 11.5 & 14.5 & $24.0 \mathrm{c}$ \\
\hline & 14 & 82.5 & 15.5 & 0.5 & 12.5 & 6.5 & $23.5 \mathrm{~cd}$ \\
\hline \multirow{2}{*}{ RPDA D } & 10 & 1.0 & 1.0 & 1.5 & 0.5 & 0 & $0.8 \mathrm{a}$ \\
\hline & 14 & 1.0 & 6.5 & 1.5 & 0.5 & 0 & $1.9 \mathrm{a}$ \\
\hline \multicolumn{2}{|c|}{ Mean for sample } & $48.6 \mathrm{~d}$ & $12.0 \mathrm{c}$ & $1.4 \mathrm{a}$ & $13.5 \mathrm{c}$ & $5.8 \mathrm{~b}$ & \\
\hline
\end{tabular}

Explanations see Table 1 
Table 6. Occurrence of Rhizopus nigricans on milk thistle seeds, using different methods and periods of incubation (percentage of infested seeds)

\begin{tabular}{|c|c|c|c|c|c|c|c|}
\hline \multirow{2}{*}{ Method } & \multirow{2}{*}{$\begin{array}{l}\text { Period of } \\
\text { incubation } \\
\text { (days) }\end{array}$} & \multicolumn{5}{|c|}{ Sample } & \multirow{2}{*}{ Mean for method } \\
\hline & & I & II & III & IV & $\mathrm{V}$ & \\
\hline \multirow{2}{*}{ DFBT } & 10 & 17.0 & 19.5 & 2.5 & 0.5 & 0 & $7.9 \mathrm{a}$ \\
\hline & 14 & 18.0 & 20.0 & 3.0 & 0.5 & 0 & $8.3 \mathrm{a}$ \\
\hline \multirow{2}{*}{$\mathrm{BT}+\mathrm{PEG}$} & 10 & 98.5 & 100.0 & 72.5 & 24.5 & 10.0 & $61.1 \mathrm{~cd}$ \\
\hline & 14 & 99.0 & 100.0 & 72.5 & 25.0 & 11.0 & $61.5 \mathrm{~cd}$ \\
\hline \multirow{2}{*}{$\mathrm{BT}+\mathrm{MAN}$} & 10 & 94.5 & 99.0 & 95.5 & 47.5 & 14.5 & $70.2 \mathrm{~d}$ \\
\hline & 14 & 94.5 & 99.0 & 95.5 & 49.0 & 16.5 & $70.9 \mathrm{~d}$ \\
\hline \multirow{2}{*}{ PDA } & 10 & 35.0 & 45.0 & 50.0 & 98.0 & 80.0 & $61.6 \mathrm{~cd}$ \\
\hline & 14 & 87.0 & 100.0 & 52.5 & 98.5 & 80.0 & $83.6 \mathrm{e}$ \\
\hline \multirow{2}{*}{ PDA D } & 10 & 75.0 & 65.0 & 50.0 & 14.0 & 10.0 & $42.8 \mathrm{~b}$ \\
\hline & 14 & 98.0 & 100.0 & 91.0 & 15.0 & 10.0 & $62.8 \mathrm{~cd}$ \\
\hline \multirow{2}{*}{ RPDA } & 10 & 30.0 & 65.0 & 35.0 & 97.0 & 56.0 & $56.6 \mathrm{~b}$ \\
\hline & 14 & 68.5 & 100.0 & 35.0 & 98.5 & 56.0 & $71.6 \mathrm{~d}$ \\
\hline \multirow{2}{*}{ RPDA D } & 10 & 23.5 & 30.0 & 50.5 & 34.0 & 15.0 & $30.6 \mathrm{~b}$ \\
\hline & 14 & 92.0 & 88.0 & 87.0 & 40.5 & 15.0 & $64.5 \mathrm{~cd}$ \\
\hline \multicolumn{2}{|c|}{ Mean for sample } & $66.5 \mathrm{~d}$ & $73.6 \mathrm{e}$ & $56.6 \mathrm{c}$ & $45.9 \mathrm{~b}$ & $26.7 \mathrm{a}$ & \\
\hline
\end{tabular}

Explanations see Table 1

only in samples IV and V. The highest number of seeds infested by these fungi was observed in the deep-freeze blotter test and on the RPDA medium, especially after longer seed incubation (Tab. 7).
In the present study, A. alternata, B. cinerea and Fusarium spp. occurred frequently on fresh seeds (samples IV and V), while Penicillium spp. and Rhizopus sp. prevailed in older samples (I, II and III).

Table 7. Occurrence of Verticillium spp. on milk thistle seeds, using different methods and periods of incubation (percentage of infested seeds)

\begin{tabular}{|c|c|c|c|c|}
\hline \multirow{2}{*}{ Method } & \multirow{2}{*}{$\begin{array}{c}\text { Period of } \\
\text { incubation } \\
\text { (days) }\end{array}$} & \multicolumn{2}{|c|}{ Sample* } & \multirow{2}{*}{ Mean for method } \\
\hline & & IV & $\mathrm{V}$ & \\
\hline \multirow{2}{*}{ DFBT } & 10 & 1.0 & 28.0 & $14.5 \mathrm{bc}$ \\
\hline & 14 & 4.5 & 53.0 & $28.8 \mathrm{e}$ \\
\hline \multirow{2}{*}{$\mathrm{BT}+\mathrm{PEG}$} & 10 & 0.5 & 2.5 & $1.5 \mathrm{a}$ \\
\hline & 14 & 1.0 & 3.5 & $2.3 \mathrm{a}$ \\
\hline \multirow{2}{*}{$\mathrm{BT}+\mathrm{MAN}$} & 10 & 0 & 2.0 & $1.0 \mathrm{a}$ \\
\hline & 14 & 0 & 2.5 & $1.3 \mathrm{a}$ \\
\hline \multirow{2}{*}{ PDA } & 10 & 0.5 & 5.0 & $2.8 \mathrm{a}$ \\
\hline & 14 & 1.0 & 15.0 & $8.0 \mathrm{~b}$ \\
\hline \multirow{2}{*}{ PDA D } & 10 & 0 & 1.5 & $0.8 \mathrm{a}$ \\
\hline & 14 & 0 & 1.5 & $0.8 \mathrm{a}$ \\
\hline \multirow{2}{*}{ RPDA } & 10 & 1.5 & 36.5 & $19.0 \mathrm{~cd}$ \\
\hline & 14 & 4.5 & 39.0 & $21.8 \mathrm{de}$ \\
\hline \multirow{2}{*}{ RPDA D } & 10 & 0.5 & 0 & $0.3 \mathrm{a}$ \\
\hline & 14 & 0.5 & 1.5 & $1.0 \mathrm{a}$ \\
\hline \multicolumn{2}{|c|}{ Mean for sample } & $1.1 \mathrm{a}$ & $13.7 \mathrm{~b}$ & \\
\hline
\end{tabular}

Explanations see Table 1 
Table 8. Effect of different methods on the detection of other fungi in tested samples after 14 days of incubation

\begin{tabular}{|c|c|c|c|}
\hline Fungus & $\begin{array}{l}\text { Maximum } \\
\text { detection in } \\
\text { the sample } \\
(\%)\end{array}$ & $\begin{array}{l}\text { Number of } \\
\text { samples in } \\
\text { which the } \\
\text { fungus was } \\
\text { detected }\end{array}$ & $\begin{array}{l}\text { Methods for which the maximum detection was recorded } \\
\text { (number of samples) }\end{array}$ \\
\hline Acremonium strictum & $1.5-75.0$ & 2 & $\operatorname{PDA}(2)$ \\
\hline Alternaria spp. & $0.5-2.0$ & 2 & DFBT(1), BT+PEG(1) \\
\hline Aspergillus spp. & $0.5-1.5$ & 4 & $\mathrm{BT}+\mathrm{PEG}(3), \operatorname{RPDA}(2), \operatorname{DFBT}(1)$ \\
\hline Aureobasidium sp. & $0.5-2.0$ & 3 & RPDA D(2), PDA D(1), RPDA(1) \\
\hline Bipolaris sp. & $0.5-1.0$ & 2 & PDA D(1), RPDA D(1) \\
\hline Cephalosporium sp. & $0.5-5.0$ & 2 & DFBT (1), RPDA(1) \\
\hline Chaetomium sp. & 0.5 & 1 & $\mathrm{BT}+\mathrm{MAN}(1), \mathrm{RPDA} \mathrm{D}(1)$ \\
\hline Epicoccum purpurascens & $0.5-13.5$ & 5 & $\operatorname{DFBT}(3), \mathrm{BT}+\mathrm{MAN}(2)$ \\
\hline Gonatobotrys simplex & $0.5-76.5$ & 4 & $\operatorname{DFBT}(2), \mathrm{BT}+\mathrm{MAN}(1), \operatorname{RPDA}(1)$ \\
\hline Mucor spp. & $0.5-24.0$ & 3 & BT+PEG(2), DFBT(1) \\
\hline Nigrospora sp. & $0.5-2.0$ & 4 & $\mathrm{BT}+\mathrm{PEG}(2), \mathrm{RPDA}(1), \mathrm{RPDA} \mathrm{D}(1)$ \\
\hline Papulaspora sp. & $0.5-5.0$ & 2 & $\operatorname{PDA}(2)$ \\
\hline Sordaria sp. & $0.5-1.0$ & 3 & $\operatorname{DFBT}(2), \operatorname{RPDA}(2)$ \\
\hline Stachybotrys sp. & 0.5 & 1 & $\operatorname{RPDA}(1)$ \\
\hline Stemphylium botryosum & $0.5-1.5$ & 5 & $\operatorname{DFBT}(2), \operatorname{RPDA}(2), \mathrm{BT}+\mathrm{MAN}(1), \operatorname{PDA} \mathrm{D}(1), \operatorname{RPDA} \mathrm{D}(1)$ \\
\hline Thamnidium elegans & 0.5 & 1 & $\mathrm{BT}+\mathrm{MAN}(1)$ \\
\hline Trichothecium sp. & $0.5-6.5$ & 4 & $\mathrm{BT}+\mathrm{MAN}(2), \mathrm{BT}+\mathrm{PEG}(1), \mathrm{PDA}(1)$ \\
\hline Trichoderma sp. & $0.5-5.0$ & 2 & $\operatorname{PDA}(1), \operatorname{RPDA}(1)$ \\
\hline Ulocladium spp. & $1.5-40.0$ & 5 & $\mathrm{BT}+\mathrm{MAN}(3), \mathrm{BT}+\mathrm{PEG}(1), \operatorname{RPDA}(1)$ \\
\hline
\end{tabular}

Explanations see Table 1

The storage conditions and intrinsic morphology of fungi are major factors in determining the length and survival of seed-borne pathogens. Hyaline fungi with thin-walled conidia, i.e. Botrytis spp. and most Fusarium spp., usually survived a shorter period of time than dematiaceous fungi (Maude 1996). However, conditions that shorten the lifespan of field pathogens promote the growth of storage fungi, mainly species of Aspergillus and Penicillium (Agarval and Sinclair 1987). Kędzia (2000) reported that high humidity conditions during storage favoured the growth of Aspergillus spp., Penicillium spp., Mucor spp. and Rhizopus spp. on herbal materials.

In the present experiment, the deep-freeze blotter test favoured the growth of most of the fungi. Niaz and Dawar (2009) observed that the deep-freeze blotter test was the best test for the detection of Fusarium spp. on maize seeds. Research by Sharfun-Nahar et al. (2005) showed that the deep-freeze blotter test was more suitable than the standard blotter test for the identification of these fungi on sunflower seeds. However, more fungal species were isolated and identified in the standard blotter test. Sultana and Ghaffar (2007) observed that the deep-freeze blotter test was useful for the detection of deep-seated and slow growing seed-borne fungi on bitter-gourd seeds. Szopińska et.al. (2012) found that the deep-freeze blotter test favoured the growth of the most of the fungi occurring on zinnia seeds. In the present experiment, the use of polyethylene glycol and mannitol were tested as an alternative to deep-freezing to prevent seed germination in blotter tests. Machado et al. (2003, 2004, 2008) observed that water restriction in the potential range of -0.6 to $-1.0 \mathrm{MPa}$ effectively inhibited seed germination and had no effect on the growth of fungi. Moreover, the authors found that at potentials from -0.3 to $-1.0 \mathrm{MPa}$, the growth of some fungi was stimulated (Machado et al. 2004). Falleiro et al. (2010) reported that the growth of A. alternata on the PDA medium was stimulated by osmotic potentials ranging from -0.35 to $-1.4 \mathrm{MPa}$. The inhibition of seed germination by the water restriction technique was also observed in the present study, but when osmotic solutes were used, they were connected with a decrease of Fusarium and Verticillium spp. detection in milk thistle seeds. However, water restriction favoured the growth of $A$. alternata, B. cinerea, Cladosporium 
spp., Penicillium spp. and $R$. nigricans. This phenomenon was also observed by Szopińska et al. (2012) in relation to zinnia seeds. The authors reported that an addition of PEG to the substrate favoured the growth of Cladosporium spp., whereas an addition of mannitol promoted the growth of Alternaria spp., B. cinerea, Cladosporium spp. and E. purpurascens. In the present experiment, agar media stimulated the growth of $A$. strictum, Aureobasidium sp., Bipolaris sp., Papulaspora sp., Stachybotrys sp. and Verticillium spp. (Tabs 7 and 8). However, the low number of samples infested by individual fungi made it difficult to draw unambiguous conclusions.

In most cases, blotter tests were more effective for the identification of fungi on milk thistle seeds than agar tests. As opposed to results by Kohen (personal communication), we did not observe significant differences in the growth of most of the fungi on PDA and RPDA mediums, with the exception of A. alternata and Verticillium spp. Disinfection of the seeds significantly decreased the number of seed infested by A. alternata, Penicillium spp. and Verticillium spp. in both agar tests, showing how many of these fungi contaminated the seeds. However, an increase in the percentage of seeds infested by B. cinerea and Cladosporium spp. was detected after this treatment, which could be due to the internal location of these fungi as well as the removal of competitive microorganisms. Moreover, the deep-seated seed infection by $B$. cinerea could be particularly dangerous due to the pathogenic properties of this fungus. The sowing of seeds infected by $B$. cinerea has resulted mainly in plant establishment problems, although there is a potential for further disease development in growing crops (Maude 1980). B. cinerea was detected at high levels in several samples in the present study. However, this pathogen was sporadically isolated from milk thistle plants (Cwalina-Ambroziak et al. 2012). So far no reports have been found on the transmission of $B$. cinerea with seeds of this plant, therefore further study on this phenomenon could be suggested.

\section{CONCLUSIONS}

1. The fungi Alternaria alternata, Botrytis cinerea, Cladosporium spp., Fusarium spp., Penicillium spp., Rhizopus nigricans and Verticillium spp. were frequently detected on milk thistle seeds.

2. The deep-freeze blotter test followed by the blotter test with an addition of mannitol and the blotter test with an addition of polyethylene glycol performed for 14 days are recommended for further study on milk thistle seed health testing.

\section{ACKNOWLEDGEMENTS}

The authors would like to thank Ms Ronit Kohen from the Volcani Centre, Official Seed Testing Lab, Bet-Dagan, Israel, for information on the reduced potato-dextrose agar medium.

\section{REFERENCES}

Agarval V.K., Sinclair J.B., 1987. Principles of seed pathology. Vol. II. CRC Press, Inc., Boca Raton, Florida, USA.

Arroyo-Manzanares N., Garcia-CAmpaña A.M., GámizGracia L., 2013. Multiclass mycotoxin analysis in Silybum marianum by ultra high performance liquid chromatography-tandem mass spectrometry using a procedure based on QuEChERS and dispersive liquid-liquid microextraction. J. Chromatogr. A 1282: 11-19. Available online at http://www.ncbi.nlm.nih. gov/pubmed/23415469; cited on 25.08.2013.

Aziz N.H., Youssef Y.A., El-Fouly M.Z., Moussa L.A., 1998. Contamination of some common medicinal plant samples and spices by fungi and their mycotoxins. Bot. Bull. Acad. Sin. 39: 279-285.

Cwalina-Ambroziak B., Wierzbowska J., Damszel M., Bowszys T., 2012. The effect of mineral fertilization on achenes yield and fungal communities isolated from the stems of milk thistle Silybum marianum (L.) Gaertner. Acta Sci. Pol., Hortorum Cultus 11(4): 157-168.

Ellis M.B., 1971. Dematiaceous Hyphomycetes. Commonwealth Mycological Institute, Kew, Surrey, England.

ElLis M.B., 1976. More dematiaceous Hyphomycetes. Commonwealth Mycological Institute, Kew, Surrey, England.

Falleiro B.A.S., Almeida P.B.A., Cautinho W.M., Suassuna N.D., Kobayasti L., 2010. Use of osmotic solutions for inhibition of sunflower seed germination in blotter test. Trop. Plant Pathol. 35(6): 343-350. Available online at http://www.scielo.br/pdf/tpp/ v35n6/a02v35n6.pdf; cited on 25.08.2013.

Ghavani N., Ramin A.A., 2007. Salinity and temperature effects on seed germination of milk thistle. Commun. Soil Sci. Plan. 38: 2681-2691.

ISTA, 2012. International Rules for Seed Testing. Annexe to Chapter 7 Seed Health Testing, Seed Health Testing Methods. The International Seed Testing Association, Bassersdorf, Switzerland.

KęDZia B., 2000. Drogi zanieczyszczenia surowców zielarskich drobnoustrojami. Herba Polonica 56(1): 35-51. (In Polish) 
Logrieco A., Moretti A., Solfrizzo M., 2009. Alternaria toxins and plant diseases: an overview of origin, occurrence and risks. World Mycotoxin J. 2(2): 129-140.

Machado J.C., Cautinho W.M., Guimarães R.M., Vieira M.G.G.C., Ferreira D.F., 2008. Use of osmotic solutes to control seed germination of rice and common bean in seed health blotter tests. Seed Sci. Technol. 36(1): 66-75.

Machado J.C., Guimaraes R.M., Vieira M.G.G.C., SouzA R.M., Pozza E.A., 2004. Use of water restriction technique in seed pathology. Seed Testing International 128: 14-18.

Machado J.C., Oliveira J.A., Vieira M.G.G.C., Alves M.C., 2003. Control of soybean seed germination in seed health tests using water restriction technique. Rev. Bras. Sementes 25(2): 77-81. Available online at http://www.scielo.br/pdf/rbs/v25n2/19652.pdf; cited on 25.08.2013. (In Portuguese)

Machowicz-Stefaniak Z., Zimowska B., 2000. Grzyby przenoszone przez materiał siewny roślin zielarskich. Acta Agrobot. 53(2): 25-38. (In Polish)

Malone J.P., Muskett A.E., 1964. Seed-borne fungi. Description of 77 fungus species. Proceeding of the International Seed Testing Association, 29 (2): 179-384.

Mathur S.B., Kongsdal O., 2003. Common laboratory seed health testing methods for detecting fungi. International Seed Testing Association, Basserdorf, Switzerland.

Maude R.B., 1980. Disease control. In: The biology of Botrytis. J.R. Colley-Smith, K. Verhoeff, W.R. Jarvis (eds), Academic Press Inc., London Ltd.

Maude R.B., 1996. Seed-borne diseases and their control. Principles and practice. CAB International, Wallingford, UK.

Morazonni P., Bombardelli E., 1995. Silybum marianum (Carduus marianus). Fitoterapia 66: 3-42.

Niaz I., Dawar S., 2009. Detection of seed-borne mycoflora in maize (Zea mays L.). Pak. J. Bot. 41(1): 443-451.

Sadowska K., 2006. Owoce ostropestu plamistego jako prozdrowotny dodatek do pieczywa. Food Sci. Technol. Quality 2(47): 290-296. (In Polish)

Sauer D.B., Burroughs R., 1986. Disinfection of seed surfaces with sodium hypochlorite. Phytopathology 76: 745-749.

Scheffer R., 1992. Ecological and evolutionary roles of the toxins from Alternaria species pathogenic to plants. In: Alternaria. Biology, plant diseases and metabolites. J. Chełkowski, A. Visconti (eds). Elsevier, Amsterdam: 101-122.

SEIDLER-ŁoŻYKOWSKA K., 2009. Medicinal plant seeds as an element of increasing biodiversity of grassland. SALVERE - Regional Workshop in Poland: 45-47.

Sharfun-Nahar, Mushataq M., Hashmi M.H., 2005. Seed-borne mycoflora of sunflower (Helianthus annus L.). Pak. J. Bot. 37(2): 451-457.
Sultana N., Ghaffar A., 2007. Seed-borne fungi associated with bitter-gourd (Momordica charantia Linn.). Pak. J. Bot. 39(6): 2121-2125.

Szopińska D., Tylkowska K., Deng Ch.J., Gao Y., 2012. Comparison of modified blotter and agar incubation methods for detecting fungi in Zinnia elegans seeds. Seed. Sci. Technol. 40: 32-42.

Tournas V.H., SApP C., Trucksess M.W., 2012. Occurrence of aflatoxins in milk thistle herbal supplements. Food Addit. Contam. 29(6): 994-999.

Watanabe T., 2002. Pictorial atlas of soil and seed fungi: Morphologies of cultured fungi and key to species. Second Edition. CRC Press, Boca Raton, London, New York, Washington D.C.

\section{PORÓWNANIE METOD WYKRYWANIA GRZYBÓW NA NASIONACH SILYBUM MARIANUM (L.) GAERTN.}

Streszczenie: Ostropest plamisty (Silybum marianum (L.) Gaertn.) jest jedną z ważniejszych roślin leczniczych uprawianych w Europie. Grzyby zasiedlające nasiona nie tylko negatywnie wpływają na ich kiełkowanie i zdrowotność, ale mogą również produkować mikotoksyny szkodliwe dla ludzi i zwierząt. Ponieważ dotychczas nie opracowano standardowej metody oceny zdrowotności nasion ostropestu celem badań było znalezienie optymalnej metody wykrywania grzybów na/w nasionach tego gatunku. Testowano następujące metody: test bibułowy $\mathrm{z}$ przemrażaniem nasion, test bibułowy $\mathrm{z}$ dodatkiem mannitolu, test bibułowy $\mathrm{z}$ dodatkiem glikolu polietylenowego, test agarowy na pożywce dekstrozowo-ziemniaczanej (PDA), test agarowy na pożywce PDA po odkażaniu nasion, test agarowy $\mathrm{z}$ zastosowaniem zubożonej pożywki PDA (RPDA) oraz test agarowy z zastosowaniem RPDA po odkażaniu nasion. Nasiona inkubowano przez 10 i 14 dni. Najczęściej identyfikowano grzyby: Alternaria alternata, Botrytis cinerea, Cladosporium spp., Fusarium spp., Penicillium spp., Rhizopus nigricans oraz Verticillium spp. Test bibułowy z przemrażaniem nasion a następnie test bibułowy $\mathrm{z}$ dodatkiem mannitolu oraz test bibułowy $\mathrm{z}$ dodatkiem glikolu polietylenowego sprzyjały wzrostowi większości ważnych grzybów, dlatego też można je polecić do dalszych badań nad oceną zdrowotności nasion ostropestu plamistego. Wykrywaniu grzybów sprzyjało także wydłużenie czasu inkubacji do 14 dni.

Received March 28, 2013; accepted August 1, 2013 